\title{
POPLARS OF CANADA
}

\section{A. J. Breitung}

$\mathrm{E}^{\mathrm{IGHT}}$ species and two varieties of poplar (Populus) are native to Canada and are commonly known as Aspens, Cottonwoods and Balsam Poplars (Plates I and II). They are usually tall, rapid-growing, short-lived trees, possessing an abundance of attractive foliage. A unique character of the Aspens and Cottonwoods is that the leaf-stalks (petioles) are flattened at right angles to the blades and this causes the leaves to tremble and rustle even in the slightest breeze. Poplar leaves, in their autumn colors, display the brightest yellow hues of our landscape.

The winter buds of certain poplar species are covered with a fragrant, sticky resin that is said to protect the enclosed, undeveloped flowers and leaves from an injury against drying out and rapid chariges of temperature. However, since not all species contain resin in their buds, other physiological factors may be responsible.

Poplar flowers are small, numerous and borne on elongated, drooping catkins, staminate (male) and pistillate (female) on separate trees (dioecious). They emerge in early spring before the leaves unfold, thus ensuring efficient wind-pollination. Petals and nectarics (honey glands) are absent, consequently the flowers do not attract insects. The staminate catkins fall soon after shedding their pollen. The pistillate catkins, however, persist until the 2- to 3-valved capsules have matured, falling before the leaves have fully developed. From the ripe capsules escape the minute, short-lived, innumerable seeds, which are borne on the wind for long distances by their cottony down. At times the air is so full of flying down as to create the effect of a snow-storm.

The wood of all poplars is soft and light and a number of species are of great commercial value, used for lumber, pulp, building, fuel, fence posts, furniture, etc.

1. Populus Sargentii Dode ( $P$. deltoides Marshall var occidentalis Rydberg). Western CotTonwood. A tree 60 to 90 feet high with large, widespreading branches forming a broad round-topped crown. Leaves broader than long, having from 5 to 15 coarse teeth on each margin and bright green on both surfaces. The sound produced by the restless leaves, beating against each other, recalls the lapping of wavelets on a pebbly shore. Habitat: river valleys; plain. Range: Man.-Alta.

2. Populus deltoides Marshall ( $P$. virginiana Fourg.; $P$. balsamifera of Sargent, not. Linnaeus). EASTERN CotTonwood. Large tree 70 to 100 feet high, the upper half is frequently divided into 3 to 5 large, spreading branches forming a broad crown. Leaves bearing from 15 to 30 teeth on each margin. Habitat: along streams. Range: s. Que.-s. Man.-s.e. Sask.

3. Populus grandidentata Michaux Largetooth Aspen. Medium-sized tree 40 to 70 feet high with spreading branches forming a narrow, roundtopped crown. Bark greenish-grey; old trunks dark and deeply furrowed. Winter buds hairy. Leaves coarsely and unevenly toothed, white-hairy when young. Habitat: well drained soil. Range: N.S.-s.e. Man. 


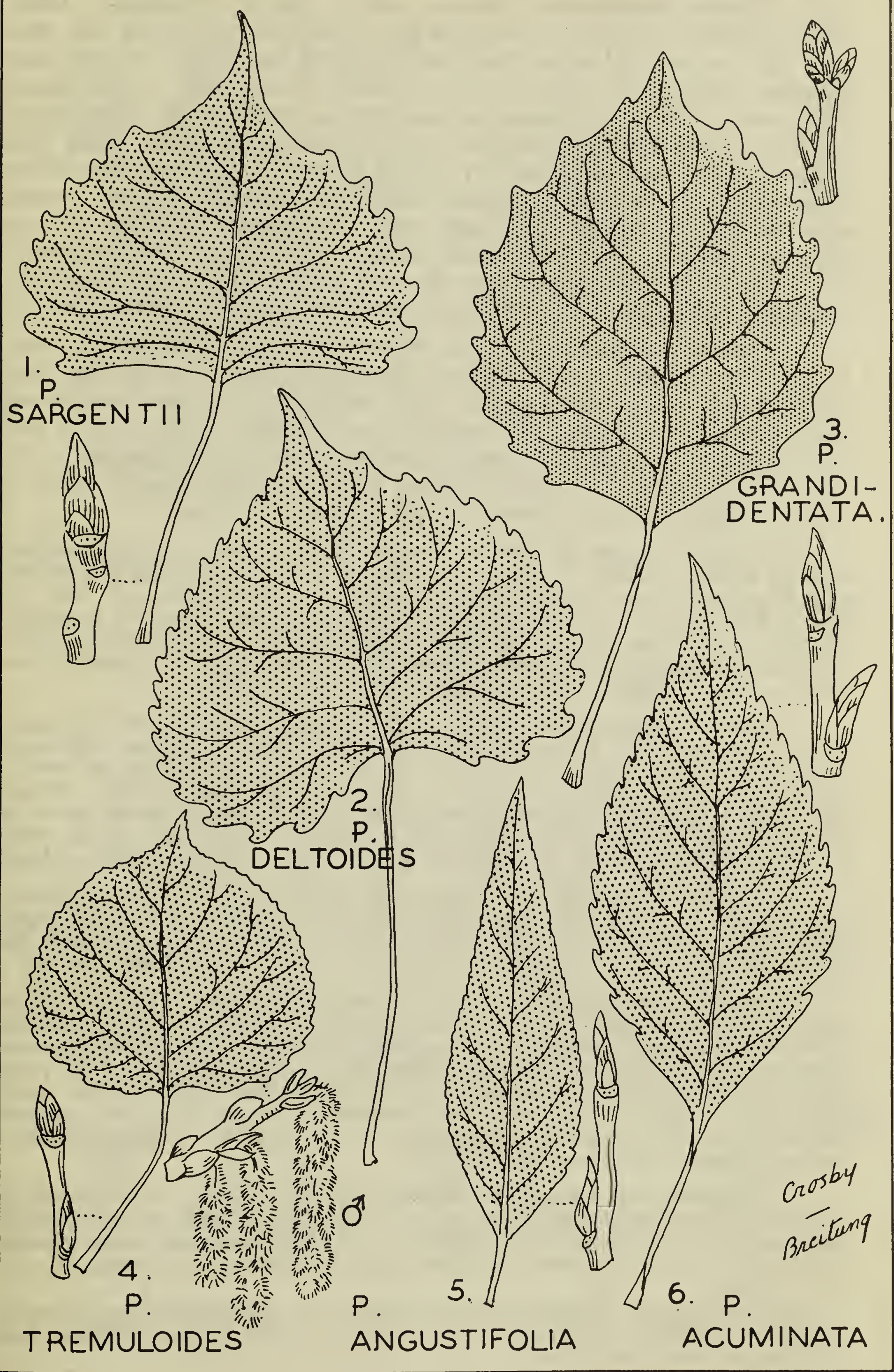


Apr., May, June, 1952

4. Populus tremuloides Michaux Aspen Poplar; Trembling Aspen; White Poplar. A tree 30 to 90 feet high; in dense stands slender and often free of branches for more than two-thirds of its length. Winter buds glabrous, shiney. The bark of trunk is usually covered with a white-mealy substance and from a distance the tree may be mistaken for White Birch. Its leaves tremble with the slightest air movement, even more readily than any of the other poplars, hence "Trembling Aspen." The silvery-grey trunks and dancing foliage, always cheerful and restive, makes the Aspen a much admired tree. It regenerates readily from root-sprouts following fire and clearing. Habitat: well drained soil. Range: Nfld.-B.C.-Yukon-Mack.

In the Prairie Provinces, Aspen occurs in a zone, known as the Park Belt. between the grassland to the south and the coniferous forest to the north.

5. Populus angustifolia James NARrow-leaved CotTonwood; WiLLow-leaved Poplar. A medium-sized, pyramidal tree 20 to 40 feet high, growing singly or in small groups. The leaves are yellowish-green above, paler and more veiny beneath; margins finely crenate; petioles 6 to $10 \mathrm{~mm}$. long; winter buds 5-scaled, resinous. Distinct from all other poplars by its very narrow leaves and short petioles resembling more closely those of willows. Habitat: along streams. Range: s. Alta.-s.w. Sask.

6. Populus acuminata Rydberg Black Cottonwood. A medium-sized tree 30 to 50 feet high with stout spreading branches forming a compact, round-topped crown. The branchlets are pale yellowish-brown and the winter buds are 6- to 7-scaled, resinous. Its leaves are lanceolate, gradually tapering at the apex, rounded or wedge-shaped at the base, coarsely toothed to crenate, bright green on both surfaces and borne on slender, slightly flattened petioles. Habitat: river valleys. Range: s.w. Alta.

7. Populus balsamifera Linnaeus ( $P$. tacamahacca Miller). BaLsAM Poplar. A tree 50 to 90 feet high; trunk 1 to 2 feet in diameter with stout erect branches; branchlets grey to brownish; winter buds saturated with a fragrant balsamic sticky resin, hence the name "Balsam Poplar." Mature leaves thin, dark glossy green above, paler beneath, veiny, mostly twice as long as broad. Stamens 20 to 30 on short filaments. Capsules oblong-ovoid, 2-valved. Habitat: poorly drained soil. Range: Nfld.-e. B.C.-Yukon-Mack.

7a. Populus balsamifera var. subcordata Hylander ( $P$. Michauxii Dode). This variety is associated with the species, differing by its broader, more heart-shaped leaves and minutely hairy petioles. It has been mistaken for the cultivated Balm-of-Gilead ( $P$. candicans Aiton) of unknown origin.

8. Populus trichocarpa Torrey \& Gray Western Balsam Poplar. A large tree 80 to 125 feet high, 3 to 4 feet in diameter with stout upright branches; branchlets lustrous, chestnut brown to reddish-yellow; winter buds resinous. Mature leaves thick, leathery, dark green above, whitish beneath with rusty resin patches, prominently veined, scarcely longer than broad; petioles minutely hairy. Stamens 40 to 60 with filaments longer than the anthers. Capsules sub-globose, 3-valved, minutely hairy. Habitat: banks of streams. Range: Yukon-B.C.-S.w. Alta.

8a. Populus trichocarpa var. hastata (Dode) Henry. This variety is associated with the species, differing by its glabrous, slightly warty capsules and narrower, more ovate-deltoid leaves. It is designated as a distinct species ( $P$. hastata Dode) by some authorities, while others do not regard it even as a variety.

Western Balsam Poplar is most abundant in the Pacific coastal region where it attains immense size, dominating the landscape, forming long picturesque lines along rivers. 


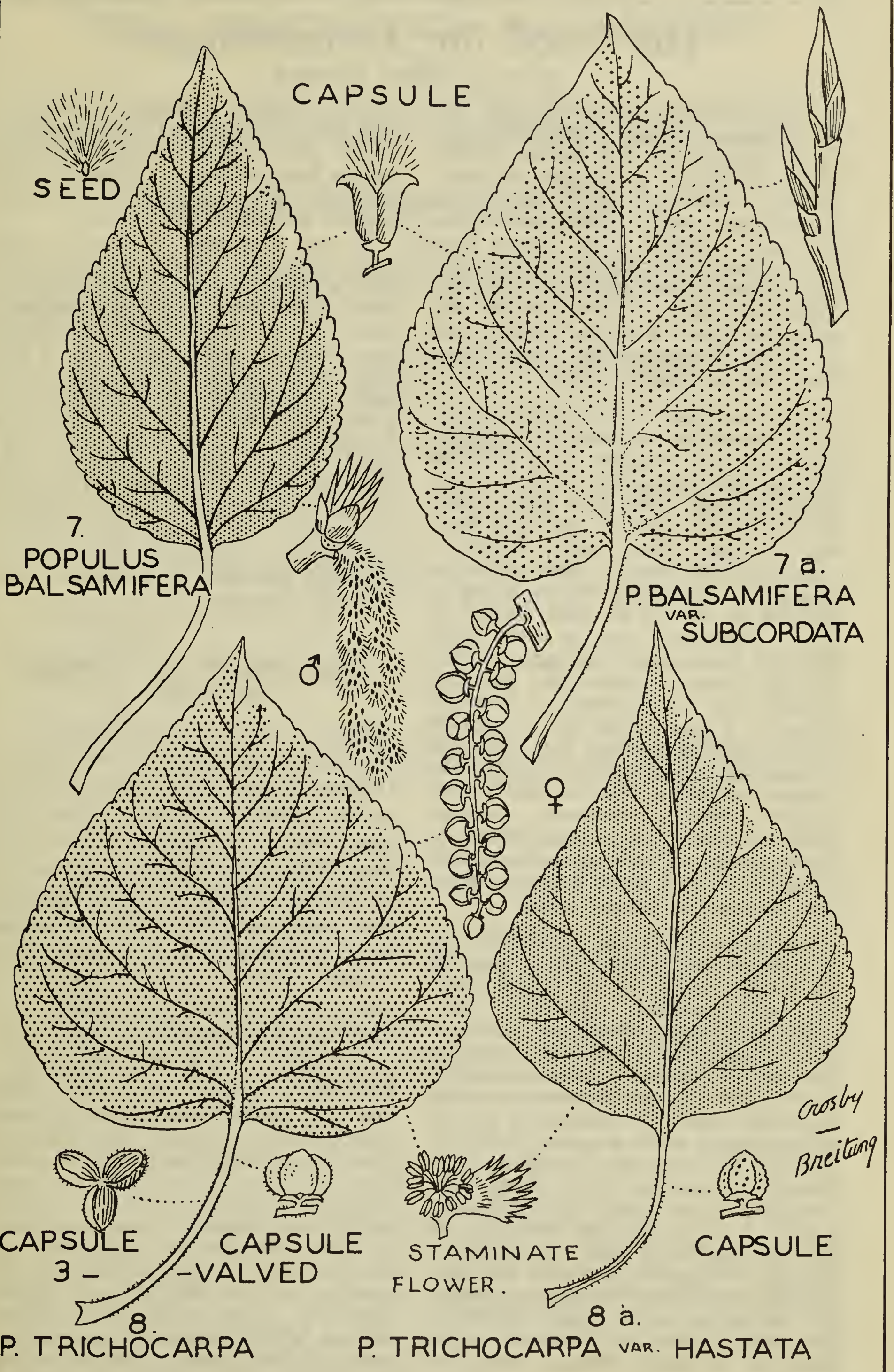

